\title{
On the alteration of the constant of elasticity of metals by the electrical current
}

\section{C.A. Mebius}

To cite this article: C.A. Mebius (1889) On the alteration of the constant of elasticity of metals by the electrical current, Philosophical Magazine Series 5, 27:165, 207-207, DOI: $10.1080 / 14786448908628337$

To link to this article: http://dx.doi.org/10.1080/14786448908628337

曲 Published online: 29 Apr 2009.

Submit your article to this journal $\sqsubset \pi$

Џ Article views: 2

Q View related articles $₫$ 
add that we may anticipate the publication of Nr. Nagaoka's further work in the Journal of the College of Science, Imperial University, Japan, in the near future.

I am, Sir,

Yours faithfully,

Glasgow University Jan. 21, $1889 . \quad$ AIKITU Takaksdate.

ON THE ALTERATION OF THE CONSTANT OF ELASTICITY OF

METALS BY THE ELECTRICAL CURRENT. BY C. A. MEBIUS.

From his investigations on the elasticity of mejals, Wertheim concluded that an electrical current, which traverses a metal wire, diminishes the coefficient of elasticity. The determinations of Wertheim are not very trustworthy, and from recent experiments Streintz has questioned the conclusions at which Wertheim arrived.

Mebius has arain taken up the question and attempted to solve it by experiments on flexure. The materials under investigation ( $t$ wo rods of steel and two of iron, two tubes of brass, one silver wire) were laid on two parallel horizontal knife-edges, and the centre was loaded. By means of a microscope with micrometer in the eyepiece, an index could be sighted. The author could not observe any direct action of the current on the bending. From a discussion of the results of the observations, it follows that in four experiments, if there had been any alteration of the coefficient of elasticity, it would have amounted to less than $0 \cdot 089,0 \cdot 015,0.047$, and 0.037 per cent. of its entire amount, and accordingly, in agreement with Streintz, he assumes that the electrical current has no action on the elasticity.-Gfvers. af k. Vet.-Akad. För.handl. 1887, p. 681 ; Beiblätter der Physik, vol. xii. p. 678 (1888).

ON AN ELECTROMETER WITH A QUARTZ DOUBLE PLATE.

BY M. JACQUES AND P. CURIE.

Two rectangular plates are cut at right angles to the axis so that their long sides are simultaneously at right angles to the optical and electrical axis. The plates are very thin, cut to a few hundredths of a millimetre, and are then cemented to each other, so that the electrical axes in them are reversed. The two external faces are silvered, and freed from the silvering on a narrow edge. If the silver coatings are brought to a difference of potential, the plate curves, as can be seen at a glass index placed at the free end of the plate. At its end a small photographed micrometer is fastened and is viewed by a microscope.

If $k=6.32 \times 10^{-8}$, the defiexion $\theta$ of the end of the needle $=\frac{3}{2} k(\mathrm{~L} / e)^{2} .(2 \lambda+\mathrm{L}) / \mathrm{L} . \mathrm{V}$ in absolute electrostatic measure (C.G.S.), where $\mathrm{L}=$ the length of the quartz plate, $e$ the thickness, $\lambda$ the length of the needle, $V$ the difference in potential in absolute measure (that is, a unit equals 290 volts).

The instrument is aperiodic, but not very sensitive, and can hence be used for higher potentials, that is from about 0.5 to several thousand volts.-Comptes Rendus, p. 1287 (1888); Beiblätter der Physik, vol, xii. p. 687. 